\title{
OPENGENALAN POLA TULISAN TANGAN AKSARA ARAB MENGGUNAKAN EKSTRAKSI FITUR DISCRETE COSINE TRANSFORM DAN KLASIFIKASI BACKPROPAGATION ARTIFICIAL NEURAL NETWORK

\author{
(Handwritten Pattern Recognition Using Discrete Cosine Transform Feature
} Extraction and Backpropagation Artificial Neural Network As Classifier)
}

\author{
Farhan Yakub Bawazir ${ }^{*}$ I Gede Pasek Suta Wijaya \\ Program Studi Teknik Informatika, Fakultas Teknik, Universitas Mataram \\ JI. Majapahit 62, Mataram, Lombok NTB, INDONESIA \\ Email: farhan.bawazir16@gmail.com,gpsutawijaya@unram.ac.id
}

\begin{abstract}
Arabic is a language that is spoken as the first or native language of more than 280 million people, most of whom live in the Middle East and North Africa. Apart from the Middle East and North Africa, Arabic is also familiar and often used in Indonesia because of the majority of Indonesia's population is Muslim and Arabic is the language of worship in Islam. The recognition of Arabic handwritten letters is one of the studies that has been done before, where the accuracy results obtained vary according to the research and methods used. This study aims to determine the accuracy resulting from the recognition of Arabic script handwriting patterns using a combination of the DCT(Discrete Cosine Transform) feature extraction method and the ANN Backpropagation classification method. The data used for this study were data from handwritten sources on A4 HVS paper using markers with categories of age from 7-13 years old and 18-23 years old with 15 respondents in each group and a total dataset image of 8400 . Testing the best model model obtained on all images produces an accuracy of $80.79 \%$, using the images of age range $17-23$ years produces $87.27 \%$ accuracy, and the images of age range 7-13 produces an accuracy of $72.84 \%$.
\end{abstract}

Keywords: pengenalan pola, tulisan tangan, aksara, DCT, backpropagation

\section{Pendahuluan}

Bahasa Arab adalah bahasa yang digunakan sebagai bahasa pertama atau bahasa asli oleh lebih dari 280 juta orang yang sebagian besar bermukim di timur tengah dan afrika utara. Selain timur tengah dan afrika utara, Bahasa Arab juga familiar dan sering digunakan di Indonesia karena mayoritas penduduk Indonesia adalah muslim dan Bahasa Arab merupakan bahasa peribadahan dalam agama Islam. Versi standar huruf Hijaiyah atau huruf Arab yang digunakan disebut dengan Modern Standard Arabic (MSA) yang merupakan sebuah versi standar yang digunakan untuk komunikasi resmi pada berbagai negara Arab[1]. Bahasa Arab terdiri atas huruf-huruf yang disebut dengan huruf hijaiyah, dimana huruf-huruf ini sangat berkaitan erat dengan Islam serta diharuskan untuk dipelajari dikarenakan huruf Hijaiyah dan Bahasa Arab digunakan pada Al-Quran dan Hadits. Sehingga, sangat penting untuk seorang muslim untuk mempelajari dan memahami huruf-huruf Hijaiyah. Mengingat betapa pentingnya huruf Hijaiyah khususnya bagi negara- negara yang menggunakan Bahasa Arab sebagai bahasa resminya serta penganut agama Islam, maka dilakukan penelitian mengenai pengenalan pola tulisan huruf Hijaiyah.

Pengenalan pola adalah mengelompokkan data numerik dan simbolik (seperti citra) secara otomatis oleh mesin (komputer). Tujuan pengenalan pola yaitu untuk mengenali suatu objek yang ada dalam citra digital. Beberapa manusia telah mengenali objek yang dilihatnya karena otak manusia telah belajar memproses satu objek dengan objek lainnya. Komputer hanya bisa menerima inputan data berupa citra objek yang akan diidentifikasi sehingga proses citra tersebut akan mengeluarkan hasil berupa informasi atau deskripsi objek di dalam citra tersebut[2].

Pengenalan pola terdiri dari pengekstraksian fitur dan pengklasifikasian. Salah satu metode ekstraksi fitur yang baik digunakan untuk pengenalan pola tulisan adalah DCT (discrete cosine transform) DCT (discrete cosine transform) merupakan sebuah teknik yang mengubah sinyal ke dalam bentuk frekuensi dasar. DCT 
dipilih pada penelitian ini karena mampu mengumpulkan informasi fitur penting pada frekuensi rendah dan fitur pada suatu citra serta dapat memberikan informasi mengenai fitur dengan kolerasi yang tinggi. DCT tidak berkorelasi dengan index frekuensi lawannya, maka dari itu apabila sebagian komponen non-dominan pada suatu citra dihapus, maka tidak akan secara signifikan mengurangi kualitas informasinya[3]. Dengan demikian, DCT merupakan metode yang cocok digunakan pada citra tulisan tangan yang memiliki background yang dominan dibandingkan dengan foreground tulisan tangan tinta hitam. Metode klasifikasi yang digunakan adalah Backpropagation Artificial Neural Network yang merupakan jaringan umpan maju multi-layer yang dilatih dengan aturan delta-learning berbasis gradientdescent atau aturan pembelajaran backpropagation[4]. Penelitian-penelitian tersebut memiliki akurasi yang tinggi, hal tersebut membuat penulis memilih metode-metode yang telah disebutkan untuk digunakan dan untuk diketahui seberapa baik kinerjanya.

Berdasarkan yang telah dipaparkan di atas, peneliti merancang model machine learning dengan metode DCT dan JST Backpropagation. Kedepannya diharapkan model ini dapat berguna dan dikembangkan untuk kebutuhan edukasi serta riset.

\section{TINJAUAN PUSTAKA}

Alfabet Arab adalah skrip yang digunakan untuk menulis beberapa bahasa Asia dan Afrika, seperti Arab, Persia, dan Urdu. Sifat kaligrafi dari aksara Arab dibedakan dari bahasa lain dalam beberapa cara. Teks arab ditulis dari kanan ke kiri, dengan alfabet memiliki 28 karakter dasar. Enam belas Huruf Arab memiliki satu hingga tiga titik. Jumlah dan posisi titik-titik ini berbeda antara karakter yang mirip. Selain itu, beberapa karakter dapat memiliki seperti zig-zag. Teks Arab bersifat kursif baik dalam teks yang dicetak dengan mesin maupun dengan tulisan tangan. Dalam sebuah kata, beberapa karakter terhubung ke karakter sebelumnya dan / atau berikutnya, dan beberapa tidak terhubung. Bentuk karakter tergantung pada posisinya dalam kata, suatu karakter mungkin memiliki hingga empat bentuk berbeda tergantung pada apakah itu terisolasi, terhubung dari kanan (bentuk akhir), terhubung dari kiri (bentuk awal), atau terhubung dari kedua sisi (bentuk tengah). Karakter dalam suatu kata mungkin tumpang tindih secara vertikal (bahkan tanpa kata sentuhan). Karakter Arab tidak memiliki ukuran tetap (tinggi dan lebar). Karakter ukuran bervariasi sesuai dengan posisinya dalam kata[5].
Penelitian dengan menggunakan DCT sebagai ekstraksi fitur dalam pengenalan pola sudah dilakukan oleh beberapa peneliti sebelumnya. Pertama adalah verifikasi tanda tangan dimana responden terdiri atas 30 orang dan masing-masing menulis tanda tangan sebanyak 15 kali, ukuran citra yang digunakan 500x500, classifier yang digunakan adalah LVQ, menghasilkan akurasi sebesar 93\%[6]. Kedua yaitu pengenalan iris mata menggunakan dataset berjumlah 420 citra, KNN sebagai classifier, pada penelitian ini, akurasi tertinggi yang didapatkan yaitu $71,67 \%[7]$. Ketiga adalah DCT sebagai metode ekstraksi fitur daun tembakau dengan dataset berjumlah 40 citra, 30 citra training dan 10 citra testing, classifier yang digunakan pada penelitian ini yaitu backpropogation ANN, menghasilkan akurasi sebesar 90\%[8].

Penelitian dengan menggunakan backpropagation sebagai classifier juga telah banyak dilakukan oleh peneliti sebelumnya. Pertama pengenalan pola karakter hindi dimana pre-processingnya terdiri atas noise reduction, binarization, normalization, dan thinning, dataset berjumlah 1000 citra dengan masingmasing 200 citra untuk setiap karakter, menghasilkan akurasi sebesar 93\%[9]. Kedua pengenalan karakter optik/karakter hasil print mesin pre-processing terdiri atas gray image conversion, noise reduction, thresholding, binarization, line extraction, character extraction, dan normalization, menghasilkan akurasi sebesar 99\% untuk angka, 97\% untuk karakter uppercase, dan 96\% untuk karakter lowercase[10]. Ketiga adalah pengenalan karakter arab dengan scope huruf yang digunakan sebanyak 28 huruf standar, dataset terdiri dari 12394 data training dan 7277 data testing, menghasilkan akurasi sebesar 96\%[11].

Berdasarkan beberapa penelitian di atas, dapat dilakukan penelitian dengan penggabungan antara metode DCT sebagai metode fitur ekstraksi pengenalan pola tulisan tangan aksara arab dengan backpropagation sebagai classifiernya.

\section{Metode Penelitian}

\subsection{Alur Penelitian}

Penelitian dimulai dari studi literatur dilakukan dengan mempelajari buku-buku, jurnal-jurnal penelitian sebelumnya serta sumber lain yang berkaitan dengan permasalahan yang diangkat pada penelitian ini. Langkah selanjutnya adalah pengumpulan data, yaitu aksara arab dengan jumlah 28 karakter. Proses pengambilan data citra aksara berdasarkan dua tingkatan, yaitu berdasarkan tulisan tangan tingkat usia 7-13 tahun dan 18-23 tahun. Dipilihnya responden berdasarkan kedua tingkatan 
tersebut dan tidak dipilihnya dengan rentang usia 1318 tahun, bertujuan untuk mendapatkan citra tulisan tangan dengan tingkat variasi yang tinggi, dimana usia 7-13 tahun masih memiliki kemampuan kognitif menulis yang masih berkembang sedangkan usia 18-23 tahun sudah memiliki kemampuan menulis yang matang, sehingga model dapat melakukan traning terhadap data yang bervariasi. Selanjutnya tahap perancangan sistem sesuai dengan rancangan yang telah dibuat. Tahap pengujian sistem dilakukan untuk menguji apakah sistem yang telah dibuat sudah berfungsi sesuai dengan tujuan. Sistem dikatakan sesuai jika sistem sudah mampu melakukan training pada dataset aksara yang ada, mampu melakukan proses klasifikasi pada suatu data baru, dan mengklasifikasikan data baru tersebut ke suatu kelas tertentu yang ada. Jika tidak, maka proses akan kembali ke tahap perancangan sistem.

\subsection{Pengambilan Dataset}

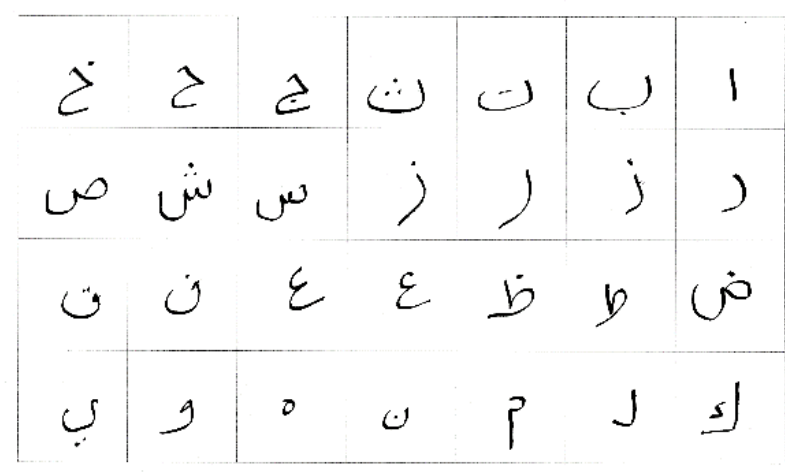

Gambar 1. Template grid tempat penulisan karakter

Pengambilan dataset citra menggunakan template dari kolom tabel dengan height dan weight yang di setting $4 \mathrm{~cm} \times 4 \mathrm{~cm}$ dengan banyak kotak sebanyak 28 kotak atau tabel sesuai dengan jumlah karakter aksara arab yaitu 28 buah, Kertas yang digunakan seragam yaitu HVS A4, seperti pada Gambar 1. Sumber pengambilan data tulisan tangan aksara arab dibagi menjadi dua tingkatan usia, yaitu usia 7-13 tahun dan usia 18-23 tahun. Pembagian kategori dari pengambilan data dilakukan agar adanya keberagaman data dari sisi pendidikan dan pernah mempelajari aksara arab sebelumnya. Masing-masing tingkatan melibatkan sepuluh orang dan masing-masing orang menuliskan sebanyak 10 kali karakter aksara arab sebanyak 28 karakter. Jadi, data yang terkumpul akhirnya sebanyak 8400 yang terdiri atas 4200 citra tulisan usia 7-13 tahun dan 4200 citra tulisan usia 18-
23 tahun yang kemudian di-scan menggunakan scanner untuk menjadikannya dalam format JPG.

\subsection{Perancangan Algoritma}

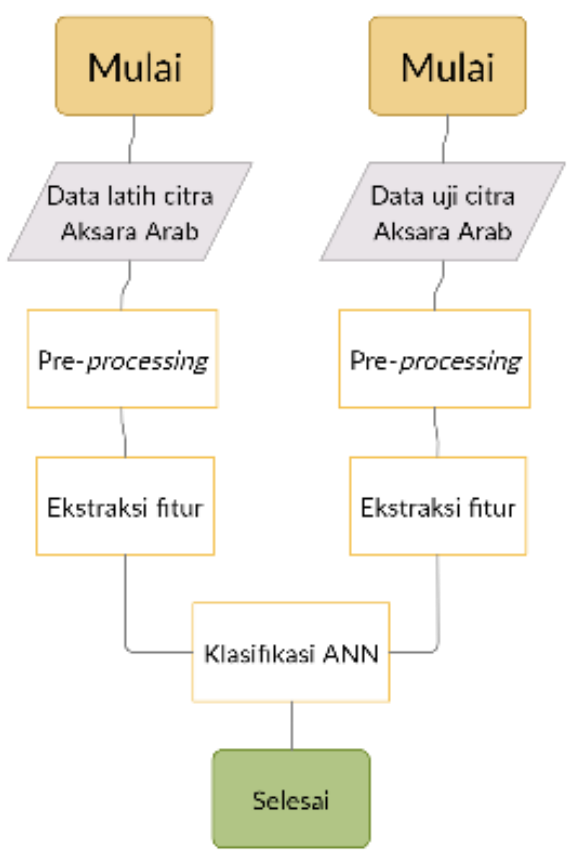

Gambar 2. Blok diagram sistem

Algoritma sistem pengenalan aksara arab ditunjukkan pada Gambar 2. Alur untuk proses pelatihan dan pengujian adalah sama, yaitu dimulai dengan me-load data citra, kemudian dilanjutkan dengan pre-processing. Selanjutnya masuk ke proses ekstraksi fitur dengan menggunakan metode LBP dan zoning, setelah fitur didapatkan maka dilakukan klasifikasi dengan menggunakan backpropagation neural network. Setelah proses mencapai parameter berhenti, maka proses akan berhenti.

\subsection{Preprocessing}

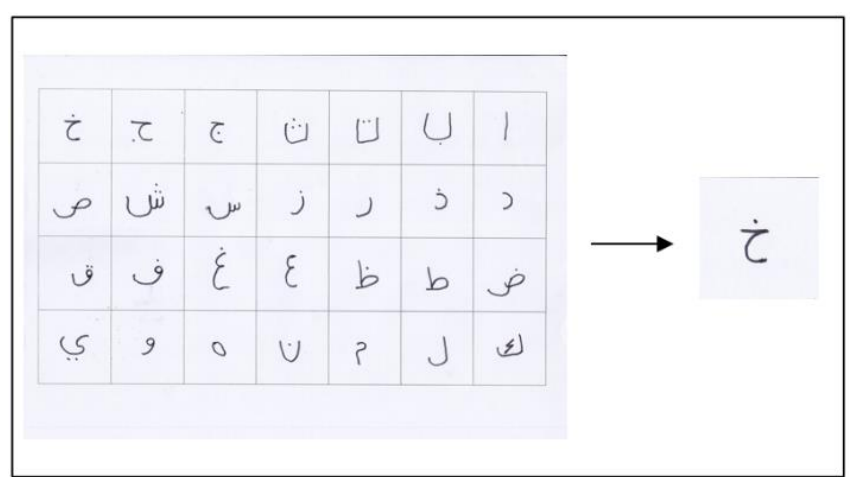

Gambar 3. Proses cropping pada citra

Garmbar 3 merupakan ilutrasi tahap awal dari preprocessing adalah dengan melakukan crop pada citra hasil scan, dimana citra dicrop untuk setiap hurufnya 
sehingga menghasilkan 28 citra untuk setiap lembar tulisan. Masing-masing responden menulis sebanyak 10 kali, menghasilkan 280 citra untuk setiap orang.

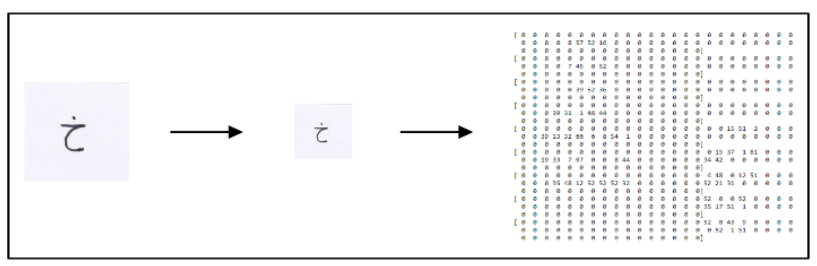

Gambar 4. Proses resize dan grayscaling

Setelah melakukan proses cropping, tahap preprocessing selanjutnya adalah melakukan resize dengan ukuran tertentu, pada penelitian ini digunakan ukuran $64 \times 64,96 \times 96$, dan $128 \times 128$. Selanjutnya adalah melakukan grayscaling guna merubah paras citra menjadi keabuan. Ilustrasinya dapat dilihat pada Gambar 4.

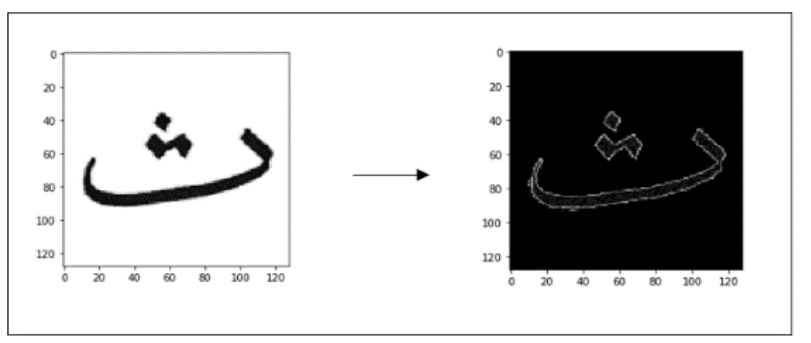

Gambar 5. Proses high pass filter pada citra

Setelah melakukan proses cropping, resizing, dan resizing, dilakukan high pass filter pada citra seperti yang dapat dilihat pada Gambar 5. Dilakukannya high pass filtering pada citra dengan tujuan untuk menajamkan citra yang berukuran kecil sehingga sehingga fitur dari citra lebih terdefinisikan, menginkatkan performa ekstraksi fitur, dan meningkatkan akurasi dari testing.

\subsection{Ekstraksi DCT}

Discrete Cosine Transform (DCT) telah banyak digunakan pada penelitian sebagai metode ekstraksi fitur maupun pada pre-processing untuk efisiensi pemilihan fitur tekstur. DCT menggunakan cosinus dari berbagai frekuensi spasial sebagai fungsi dasar dan umumnya dikenal karena penerapannya dalam standar kompresi JPEG. Pada penelitian[12], dilakukan kompresi citra secara maksimal dengan metode DCT dan algoritma Huffman pada proses kuantisasi, kemudian DCT juga digunakan sebagai ekstraksi fitur yang dipadukan dengan LBP pada citra tanda tangan dengan akurasi testing sebesar 93\%[12]. Selain itu, DCT juga dapat digunakan sebagai preprocessing seperti pada penelitian mengenai identifikasi fitur wajah, dimana DCT memperbaiki kekurangan pada metode LDA dan PCA yang digunakan sebagai ekstraksi fitur[3]. Pada penelitian ini, DCT digunakan sebagai ekstraksi fitur. Untuk ekstraksi fitur, Sebagian besar energi sinyal terletak pada komponen frekuensi rendah, yang mana muncul di sudut kiri atas DCT. DCT mengubah informasi spasial ke dalam domain frekuensi, fitur tekstur dapat didefinisikan sebagai spektrum energi di berbagai lokasi blok lokal. Karena koefisien DC mewakili nilai rata-rata skala abu-abu dari setiap blok $\mathrm{N} \times \mathrm{N}$, maka informasi tekstur yang didapat kurang spesifik detail tekstur yang diekstraksi. DCT merupakan metode berbasis penampilan lokal yang memiliki sifat-sifat seperti de-korelasi, Keterpisahan, pemadatan energi, simetris, Orthogonal. Komponen frekuensi rendah tersimpan di sudut kiri atas. Komponen-komponen ini dapat diekstraksi untuk pengklasifikasian citra.

Penelitian ini, mengekstraksi fitur pada tulisan tangan dengan mengaplikasikan DCT dimana nilai derajat keabuan setiap piksel dalam citra dinormalisasi menjadi 128 melalui operasi substraction. Kemudian, citra dibagi menjadi $8 \times 8$ blok, dan setiap blok diproses dengan operasi 2D-DCT seperti pada persamaan(1). $C(u, v)=$

$a(u) a(v) \sum_{x=0}^{N-1} \sum_{y=0}^{N-1} f(x, y) \cos \left[\frac{(2 x+1) \pi \mu}{2 N}\right] \cos \left[\frac{(2 y+1) \pi \mu}{2 N}\right]$

Selama proses DCT berlangsung, dihitung pula invers dari 2D-DCT dengan menggunakan persamaan $(2-12)[8]$.

$f(x, y)=\sum_{x=0}^{N-1} \sum_{y=0}^{N-1} f(x, y) \cos \left[\frac{(2 x+1) \pi \mu}{2 N}\right] \cos \left[\frac{(2 y+1) \pi \mu}{2 N}\right]$

Matriks hasil transformasi DCT yang telah terisi dengan koefisien DCT selanjutnya diproses pada tahap kuantisasi, dimana data yang terletak pada kiri atas merupakan korelasi dari frekuensi-frekuensi rendah dari data asli. Sedangkan yang terletak pada kanan bawah merupakan korelasi dari frekuensi-frekuensi tinggi dari data asli.

Pada tahap kuantitasi, digunakan algoritma Huffman yaitu dengan Menyusun bilangan menggunakan fungsi zigzag scanning[12]. Proses ini bertujuan untuk menentukan fitur terbaik dari citra yang selanjutnya akan diproses pada tahap klasifikasi, dimana jumlah fitur yang diambil sejumlah nilai koefisien yang digunakan 


\subsection{Klasifikasi Backpropagation}

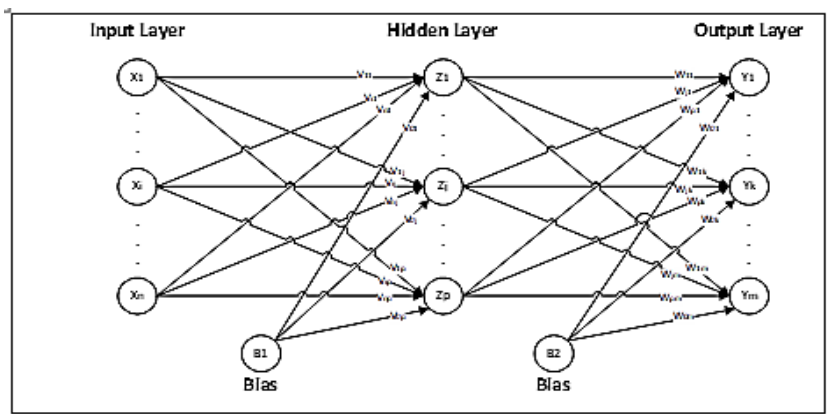

Gambar 6. Arsitektur jaringan backpropagation

Backpropagation memiliki sejumlah neuron yang ada dalam satu atau lebih hidden layer. Gambar 6 merupakan model arsitektur backpropagation multilayer dengan 1 hidden layer. Pada Gambar 8 neuron input dilambangkan dengan $\mathrm{X}$, neuron hidden dilambangkan dengan $Z$, dan neuron output dilambangkan dengan $\mathrm{Y}$. Bobot antara neuron input $\mathrm{X}$ dan neuron hidden $\mathrm{Z}$ dilambangkan dengan $\mathrm{V}$, sedangkan bobot antara neuron hidden $\mathrm{Z}$ dan neuron output $\mathrm{Y}$ dilambangkan dengan $\mathrm{W}$.

\subsection{Teknik Pengujian}

Tahapan pengujian sistem bertujuan untuk melakukan benchmark sistem, sehingga dapat diketahui apakah sistem berjalan baik serta dapat diketahui kekurangan yang terdapat pada sistem. Berikut perhitungan akurasi, presisi dan recall dalam pengujian sistem:

$$
\begin{gathered}
\text { Akurasi }=\frac{\text { jumlah data sesuai target }}{\text { Total keseluruhan data }} \\
\text { Presisi }=\frac{\text { jml data yang sesuai target di satu kelas }}{\text { jml seluruh data yang sesuai target }} \\
\text { Recall }=\frac{\text { jml data yang sesuai target di satu kelas }}{\text { jml data di satu kelas }}
\end{gathered}
$$

\section{HASIL DAN PEMBAHASAN}

\subsection{Skenario Pengujian}

Dataset yang digunakan untuk pencarian model ini adalah dataset tulisan tangan aksara arab dengan jenis spidol yang sama pada 30 orang untuk proses training dan testing pada citra, dimana dataset yang digunakan adalah dataset yang telah disebutkan sebelumnya yaitu dataset PSTI Unram yang terdiri dari 4200 citra tulisan usia 7-13 tahun dan 4200 citra usia 18-23 tahun, yang masing-masing terdiri atas 15 orang. Kemudian, dilakukan pengujian terhadap model yang telah dibangun menggunakan dataset yang ada. Pengujian ini dilakukan dengan berbagai parameter dengan urutan pengujian sebagai berikut.
1. Ukuran citra yaitu $64 \times 64,96 \times 96$, dan $128 \times 128$.

2. Koefisien DCT 48-256.

3. Learning rate $(0.1 \sim 0.5)$.

4. Klasifikasi backpropagataion

5. Pembagian data training dan testing $80: 20$
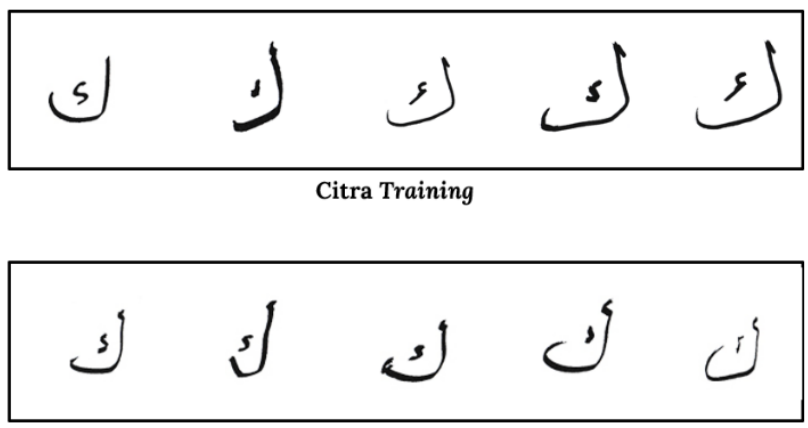

Citra Testing

Gambar 10. Contoh citra training dan testing

\subsection{Hasil Pengujian Terhadap Skenario Uji}

\subsubsection{Pengujian Koefisien DCT}

Dilakukan pencarian terhadap nilai koefisien DCT yang memiliki nilai optimum untuk mencapai akurasi teringgi dengan menggunakan ukuran citra $128 \times 128$, learning rate 0.001 , hidden layer berjumlah 2 buah dengan masing-masing neuron berjumlah 128 , sesuai dengan model terbaik pada penelitian [13].

TABEL I. HASIL PENGUJIAN KOEFISIEN DCT

\begin{tabular}{|c|c|c|}
\hline Koefisien & Akurasi Training & Akurasi Testing \\
\hline 48 & $99.78 \%$ & $74.76 \%$ \\
\hline 64 & $98.02 \%$ & $74.82 \%$ \\
\hline 81 & $99.93 \%$ & $76.34 \%$ \\
\hline 96 & $99.94 \%$ & $76.01 \%$ \\
\hline 100 & $99.91 \%$ & $75.89 \%$ \\
\hline 144 & $99.94 \%$ & $75.06 \%$ \\
\hline 196 & $99.94 \%$ & $73.75 \%$ \\
\hline 256 & $99.94 \%$ & $72.26 \%$ \\
\hline
\end{tabular}

Berdasarkan TABEL I didapatkan bahwa akurasi terbaik diperoleh pada koefisien DCT 81 dengan akurasi training yaitu $99.93 \%$ dan akurasi testing $76.34 \%$.

\subsubsection{Pengaruh Jumlah Neuron, Hidden Layer, dan Dropout}

Pengujian ini bertujuan untuk mengetahui pengaruh jumlah neuron, jumlah hidden layer, dan 
dropout terbaik untuk mendapatkan hasil akurasi tinggi pada tahapan testing. Diujikan 6 hidden layer yang berbeda dengan masing-masing neuron di setiap hidden layer sebanyak 32, 64, 128, 256, 384, dan 512 neuron. Ukuran citra yang digunakan yaitu $128 \times 128$ dengan jumlah koefisien DCT sebanyak 81 sesuai hasil terbaik yang didapat dari pengujian sebelumnya. Sedangkan learning rate yang digunakan yaitu 0,001 dan epoch 1000 pada backpropagation. Berikut adalah hasil terbaik yang didapatkan dari masing-masing jumlah Neuron.

TABEL II. HASIL PENGUJIAN NEURON, HL, DAN DROPOUT

\begin{tabular}{|l|c|c|c|c|c|c|}
\hline $\begin{array}{l}\text { Jumlah } \\
\text { Neuron }\end{array}$ & $\begin{array}{c}\text { Jumlah } \\
\text { HL }\end{array}$ & $\begin{array}{c}\text { Drop } \\
\text { out }\end{array}$ & $\begin{array}{c}\text { Accura } \\
\text { cy (\%) }\end{array}$ & $\begin{array}{c}\text { Precisi } \\
\text { on (\%) }\end{array}$ & $\begin{array}{c}\text { Recall } \\
(\%)\end{array}$ & $\begin{array}{c}\text { Time } \\
(\mathrm{s})\end{array}$ \\
\hline 32 & 2 & 0,2 & 66,67 & 81,61 & 49,94 & 65,39 \\
\hline 64 & 3 & 0,2 & 73,10 & 79,80 & 67,98 & $\begin{array}{c}102,4 \\
6\end{array}$ \\
\hline 128 & 3 & 0,2 & 79,23 & 81,14 & 77,86 & $\begin{array}{c}167,2 \\
4\end{array}$ \\
\hline 256 & 2 & 0,2 & 81,43 & 81,94 & 80,77 & $\begin{array}{c}156,1 \\
1\end{array}$ \\
\hline 384 & 2 & 0,4 & 81,19 & 82,23 & 80,71 & $\begin{array}{c}252,2 \\
8\end{array}$ \\
\hline 512 & 2 & 0,4 & 81,90 & 82,35 & 81,37 & $\begin{array}{c}396,9 \\
7\end{array}$ \\
\hline
\end{tabular}

Berdasarkan TABEL II didapatkan hasil tertinggi pada 512 neuron dengan menggunakan 2 hidden layer dan dropout sebesar 0.4, menghasilkan akurasi sebesar $81.90 \%$.

\subsubsection{Pengaruh Learning Rate}

Pengujian ini bertujuan untuk mengetahui pengaruh dari learning rate sebagai parameter training untuk mengkoreksi weight (bobot) pada proses training. Learning rate yang digunakan yaitu dari 0.001-0.005 dikarenakan pada penelitian [14] didapatkan bahwa learning rate 0.001 dan 0.005 menghasilkan akurasi terbaik dan memiliki jumlah epoch terendah untuk mencapai akurasi yang tertinggi. Model yang digunakan pada pengujian learning rate ini yaitu menggunakan 2 hidden layer dengan masingmasing layer berjumlah 512 dengan dropout sebesar 0.4 . Citra yang diuji menggunakan ukuran $128 \times 128$ dan koefisien DCT sebesar 81. Hasil yang didapat ditunjukkan pada TABEL III.

TABEL III. HASIL PENGUIIAN LEARNING RATE

\begin{tabular}{|c|c|c|c|c|}
\hline $\begin{array}{c}\text { Learning } \\
\text { Rate }\end{array}$ & $\begin{array}{c}\text { Accuracy } \\
(\%)\end{array}$ & $\begin{array}{c}\text { Precision } \\
(\%)\end{array}$ & $\begin{array}{c}\text { Recall } \\
(\%)\end{array}$ & Time (s) \\
\hline
\end{tabular}

\begin{tabular}{|l|c|c|c|c|}
\hline 0.001 & 81,90 & 82,35 & 81,37 & 396,972 \\
\hline 0.002 & 79,94 & 80,17 & 79,88 & 421.480 \\
\hline 0.003 & 78,69 & 78,96 & 77,86 & 423.912 \\
\hline 0.004 & 77,86 & 77,90 & 77,86 & 401.898 \\
\hline 0.005 & 76,85 & 76,94 & 76,85 & 409.862 \\
\hline
\end{tabular}

Akurasi tertinggi yang didapat pada TABEL III adalah $81,90 \%$ dengan presisi $82,35 \%$ dan recall $79,88 \%$ pada learning rate 0,001. Berdasarkan hasil yang didapat, dapat dilihat seiring dengan bertambahnya learning rate maka accuracy, precision, dan recall akan menurun. Sedangkan waktu komputasi untuk pengujian tidak berbeda jauh, dalam rentang 390s-420s.

\subsubsection{Pengaruh ukuran citra}

Pengujian ini bertujuan untuk mengetahui pengaruh ukuran citra dalam akurasi yang akan dihasilkan. Pada penelitian ini ukuran citra yang akan diuji adalah 3 ukuran citra yaitu 64x64, 96x96 dan $128 \times 128$ menggunakan model terbaik yang didapatkan pada pengujian sebelumnya.

TABEL IV. HASIL PENGUJIAN UKURAN CITRA

\begin{tabular}{|c|c|c|c|c|}
\hline $\begin{array}{c}\text { Ukuran } \\
\text { Citra }\end{array}$ & $\begin{array}{c}\text { Accuracy } \\
(\%)\end{array}$ & $\begin{array}{c}\text { Precision } \\
(\%)\end{array}$ & Recall (\%) & Time (s) \\
\hline $64 \times 64$ & 82,80 & 83,18 & 82,74 & 456.934 \\
\hline $96 \times 96$ & 82,08 & 82,83 & 81,85 & 441.452 \\
\hline $128 \times 128$ & 81,90 & 82,35 & 81,37 & 396.472 \\
\hline
\end{tabular}

Berdasarkan hasil pengujian TABEL IV, ukuran citra $64 \times 64$ memiliki hasil tertinggi, yaitu akurasi $82.80 \%$, presisi $83.18 \%$, recall $82.74 \%$, dan waktu komputasi $456.934 \mathrm{~s}$. Sehingga arsitektur terbaik pada pengujian terhadap ukuran citra masukan adalah citra $128 \times 128$. Untuk waktu komputasi ukuran citra 128×128 memiliki waktu komputasi tercepat dibandingkan dengan ukuran citra $64 \times 64$ dan 96x96, Hal ini dikarenakan pengaruh koefisien DCT pada citra ukuran $128 \times 128$ lebih kecil dibandingkan ukuran citra lainnya.

Berdasarkan hasil pengujian, didapatkan model terbaik dengan parameter 2 hidden layer, dengan masing-masing layer berjumlah 512 neuron, 81 koefisien DCT, dropout 0.4, ukuran citra 64×64, dan learning rate 0.001 .

\subsection{Pengujian Model}

Pengujian model dilakukan terhadap seluruh dataset yang berjumlah 8400 citra, dataset citra usia 7- 
13 tahun berjumlah 4200, dan dataset usia 18-23 tahun berjumlah 4200 dengan menggunakan model terbaik dari hasil pengujian di atas. Pengujian ini memiliki tujuan untuk mengetahui akurasi dari ketiga kategori dataset tersebut pada tahapan testing. Pengujian ini menggunakan $k$-fold cross validation dengan sebanyak 10 fold. Model yang digunakan adalah model terbaik yang telah didapatkan pada pengujian sebelumnya.

\subsubsection{Pengujian model pada fitur DCT}

Pengujian ini bertujuan untuk mengetahui performa fitur DCT pada model, dimana model yang digunakan adalah model terbaik yang telah didapatkan sebelumnya. Berikut pada TABEL $\mathrm{V}$ adalah hasil yang didapatkan.

TABEL V. HASIL PENGUJIAN DATASET DENGAN DCT

\begin{tabular}{|c|c|c|c|c|c|}
\hline Citra & $\begin{array}{c}\text { Trainin } \\
g(\%)\end{array}$ & $\begin{array}{c}\text { Testin } \\
g(\%)\end{array}$ & $\begin{array}{c}\text { Precisio } \\
n(\%)\end{array}$ & $\begin{array}{c}\text { Recall } \\
(\%)\end{array}$ & Time (s) \\
\hline Seluruh & 99,94 & 80,79 & 81,13 & 80,45 & 4006.083 \\
\hline Usia 18-23 & 99,91 & 87,27 & 87,47 & 87,20 & 2119.2383 \\
\hline Usia 7-13 & 1.0 & 72,84 & 73,33 & 72,40 & 2135.0436 \\
\hline
\end{tabular}

Didapatkan bahwa citra usia 18-23 tahun memiliki akurasi yang tertinggi yaitu $87.27 \%$, citra usia $7-13$ tahun memiliki akurasi terendah yaitu $72.84 \%$. Hal ini terjadi karena pada citra tulisan tangan usia 18-23 tahun lebih tebal, besar, dan rapi dibandingkan dengan tulisan usia 7-13 tahun yang cenderung lebih kecil, kurang tebal, dan bahkan ada beberapa huruf yang terlihat mirip dalam penulisannya. Hal ini menyebabkan model sulit untuk mempelajari citra dengan benar.

\subsubsection{Pengujian model pada DCT + LBP}

Pengujian ini bertujuan untuk mengetahui performa fitur DCT apabila dipadukan dengan LBP seperti pada penelitian [6], dimana model yang digunakan adalah model terbaik yang telah didapatkan sebelumnya. Berikut pada TABEL VI adalah hasil yang didapatkan.

TABEL VI. HASIL PENGUJIAN DATASET DENGAN DCT + LBP

\begin{tabular}{|c|c|c|c|c|c|}
\hline Citra & $\begin{array}{c}\text { Akurasi } \\
\text { Training } \\
(\%)\end{array}$ & $\begin{array}{c}\text { Akurasi } \\
\text { Testing } \\
(\%)\end{array}$ & $\begin{array}{c}\text { Precision } \\
(\%)\end{array}$ & $\begin{array}{c}\text { Recall } \\
(\%)\end{array}$ & Time (s) \\
\hline Seluruh & 74,73 & 64,83 & 80,97 & 45,29 & 4318.214 \\
\hline Usia 18-23 & 93,77 & 79,46 & 82,98 & 76,16 & 1988.484 \\
\hline Usia 7-13 & 71,49 & 57,88 & 77,09 & 36,39 & 2073.009 \\
\hline
\end{tabular}

Sama seperti pengujian sebelumnya, Didapatkan citra usia 18-23 tahun memiliki akurasi yang tertinggi yaitu $79.46 \%$, citra usia 7-13 tahun memiliki akurasi terendah yaitu $57.88 \%$. Hasil LBP + DCT lebih rendah dibandingkan dengan DCT dikarenakan tidak dapat bekerja secara maksimal untuk mendapatkan fitur- fitur penting yang ada pada citra apabila citra ditransformasikan ke dalam bentuk LBP. Pada penelitian [6] didapatkan akurasi testing pada penggunaan fitur DCT sebesar sebesar 93\% dan dengan penggunaan fitur DCT + LBP memiliki hasil yang lebih rendah yaitu sebesar 91\%, dimana pada penelitian tersebut memiliki kesamaan dengan penelitian ini yaitu fitur LBP dan DCT digunakan pada citra yang cenderung memiliki background putih yang dominan dibandingkan dengan foreground tinta tulisan tangan yang berwarna hitam. Sehingga terdapat tendensi bahwa metode LBP kurang baik digunakan untuk citra yang memiliki background putih yang dominan terhadap foreground-nya.

\section{KESIMPULAN DAN SARAN}

\subsection{Kesimpulan}

Berdasarkan penelitian yang sudah dilakukan, berikut kesimpulan yang bisa disimpulkan oleh penulis. Model terbaik yang dihasilkan pada penelitian ini yaitu menggunakan size citra 64, jumlah koefisien DCT 81, 2 hidden layer dengan masing-masing neuron di hidden layer bernilai 514, dropout sebesar 0.4, dan learning rate 0,001 . Hasil pengujian menggunakan ekstraksi fitur LBP dan LBP+DCT berbeda signifikan, dimana LBP+DCT menghasilkan akurasi 64.83\% sedangkan DCT only menghasilkan akurasi $80.79 \%$.

Metode DCT menghasilkan akurasi yang lebih tinggi dibandingkan dengan DCT+LBP karena LBP menghambat kinerja dari DCT untuk mengekstrak fiturfitur penting dengan baik dan maksimal pada citra yang sudah ditransformasikan ke dalam bentuk LBP. Pengujian terhadap citra tulisan tangan rentang usia 713 tahun dan rentang usia 18-27 tahun menghasilkan akurasi yang berbeda. Citra tulisan tangan usia 18-23 tahun memiliki akurasi yang lebih tinggi, yaitu $87.27 \%$ untuk DCT only dan 79.46\% untuk DCT+LBP. Sedangkan pada citra usia 7-13 tahun menghasilkan akurasi 72.84\% untuk DCT only dan 57.88\% untuk DCT+LBP. Hal ini disebabkan perbedaan cara pengambilan data dan preprocessing. Hal ini menunjukkan pengambilan data dan persiapan data sebelum masuk ke tahap selanjutnya sangat mempengaruhi akurasi yang akan dihasilkan.

\subsection{Saran}

Ada beberapa saran yang dapat penulis berikan untuk penelitian kedepannya, berikut saran penulis. Penulisan aksara harus besar dan tebal, sehingga didapatkan hasil yang maksimal. Selain itu, menambahkan pre-processing skeletonization untuk 
mendapatkan ukuran tulisan yang memiliki ketebalan yang sama sehingga didapatkan hasil yang lebih baik.

\section{UCAPAN TERIMA KASIH}

Terima kasih saya ucapkan kepada rekan-rekan informatika 16 yang telah membantu dalam pengerjaan penelitian ini serta responden yang telah berkontribusi untuk menyediakan data yang digunakan pada penelitian model machine learning ini.

\section{DAFTAR PUSTAKa}

[1] T. Akhir, "Analisa Dan Implementasi Metode Kohonen Neural Network Untuk Pengenalan Karakter Huruf Arab," 2012.

[2] Vidia, "Pengenalan Tulisan Tangan Bahasa Arab Menggunakan Metode Probabilistic Neural Network," J. Ilmu Komput. dan Desain Komun. Vis., vol. 4, no. 1, pp. 28-35, 2019.

[3] I. G. P. S. Wijaya, K. Uchimura, and Z. Hu, "Face Recognition Based on Dominant Frequency Features and Multiresolution Metric," Int. J. Immovative Comput. Inf. Control, vol. 5, no. 1349-4198, pp. 641651, 2009.

[4] T. F. Abidin, A. A. AzZuhri, and F. Arnia, "Pengenalan Karakter Plat Nomor Kendaraan Bermotor Menggunakan Zoning dan Fitur Freeman Chain Code," J. Rekayasa Elektr., vol. 14, no. 1, pp. 19-25, 2018, doi: 10.17529/jre.v14i1.8932.

[5] M. T. Parvez and S. A. Mahmoud, "Offline arabic handwritten text recognition: A survey," ACM Comput. Surv., vol. 45, no. 2, 2013, doi: 10.1145/2431211.2431222.

[6] M. W. Andani, G. S. Nugraha, P. Studi, T. Informatika, F. Teknik, and U. Mataram, "( Signature Verification Using Feature of LBP and DCT With LVQ Classifier )," vol. 2, no. 1, pp. 208-216, 2020.

[7] F. E. Alfian, I. G. P. S. Wijaya, and F. Bimantoro,
"Identifikasi Iris Mata Menggunakan Metode Wavelet Daubechies dan K-Nearest Neighbor," J. Teknol. Informasi, Komputer, dan Apl. (JTIKA ), vol. 2, no. 1, pp. 1-10, 2020, doi: 10.29303/jtika.v2i1.76.

[8] R. V. Nahari, A. S. Editya, and R. Alfita, "Ekstraksi Fitur Daun Tembakau Berbasis Discrete Cosine Transform ( DCT )," J. Appl. Informatics Comput., vol. 4, no. 1, pp. 8-12, 2020.

[9] P. S. P. Kosbatwar and A. Prof, "Recognition of Characters Using Back-Propagation Neural Network," Int. J. Comput. Sci. Inf. Technol., vol. 3, no. March, pp. 6-7, 2009.

[10] S. Afroge, B. Ahmed, and F. Mahmud, "Optical character recognition using back propagation neural network," ICECTE 2016 - 2nd Int. Conf. Electr. Comput. Telecommun. Eng., vol. 3, no. 2, pp. 1-8, 2017, doi: 10.1109/ICECTE.2016.7879615.

[11] H. A. A., "Back Propagation Neural Network Arabic Characters Classification Module Utilizing Microsoft Word," J. Comput. Sci., vol. 4, no. 9, pp. 744-751, 2008, doi: 10.3844/jcssp.2008.744.751.

[12] N. Rahmadani, B. D. Setiawan, and S. Adinugroho, "Prediksi Ketinggian Gelombang Laut Menggunakan Metode Jaringan Saraf Tiruan Backpropagation," Pengemb. Teknol. Inf. dan IImu Komput., vol. 3, no. 7, pp. 6517-6525, 2019.

[13] A. A. S. Mas, K. Maharani, and F. Bimantoro, "Pengenalan Pola Tulisan Tangan Aksara Sasak Menggunakan Metode Linear Discriminant Analysis Dan Jaringan Syaraf Tiruan Jenis Backpropagation ( Handwritten Sasak Script Recognition Using Linear Discriminant Analysis And Backpropagation Artificial Neural Ne," vol. 2, no. 1, pp. 237-247, 2020.

[14] D. R. Wilson and T. R. Martinez, "The need for small learning rates on large problems," Proc. Int. Jt. Conf. Neural Networks, vol. 1, pp. 115-119, 2001, doi: 10.1109/ijcnn.2001.939002. 